KAROL KARP

Uniwersytet Mikołaja Kopernika w Toruniu

\title{
Brexit we włoskiej literaturze współczesnej: Città irreale (Nierealne miasto) Cristiny Marconi, Brexit Blues (Brexitowy blues) Marca Varvella i La mia Brexit (Mój brexit) Francesca De Carla
}

Włoska literatura współczesna nie pozostaje obojętna wobec ważnych wydarzeń społecznych oraz coraz częściej bezpośrednio nawiązuje do życia i działalności znanych postaci świata polityki. Podobnie jak w innych literaturach europejskich, również we włoskiej można mówić o znaczącym rozwoju gatunku political fiction od przełomu xx i xxI wieku1. W tym kontekście warto wspomnieć o grupie utworów ukazujących sylwetkę kontrowersyjnego Silvia Berlusconiego².

1 Zob. Berezowski 2013. O gatunku political fiction w polskiej literaturze pierwszej dekady XXI wieku pisze Halina Janaszek-Ivaničkowá (2012). W swoim artykule badaczka analizuje definicję political fiction $\mathrm{w}$ wybranych dokumentach naukowych, aby następnie skoncentrować się na dwóch ważnych utworach pod tytułem Żona prezydenta (2006) Stefana Chwina oraz Doczekaj nowiu (2007) Piotra Wojciechowskiego i stwierdzić, że stanowią one „przykłady znaczące tej nowej political fiction, której tematem staje się coraz częściej rola służb specjalnych w świecie aktualnej demokracji zwalczającej terroryzm metodami terrorystycznymi” (Janaszek-Ivaničkowá 2012: 107).

2 Obrazowanie Berlusconiego we włoskiej kulturze ma wieloaspektowy charakter. Oprócz literatury dotyczy ono również filmu, felietonów i artykułów naukowych. O popularności polityka dobitnie świadczy fakt, że krytyka powszechnie stosuje pojęcie „berlusconizm”, aby podkreślić jego wpływ na życie ludzi w Italii. Fenomen Berlusconiego - zwłaszcza w kontekście kultury politycznej - analizuje w ciekawy sposób Karolina Golemo (2013). Wśród innych godnych uwagi polskojęzycznych opracowań odwołujących się do Berlusconiego wymienię artykuł Łukasza Berezowskiego (2009). 
Jako przykład podam dwie interesujące powieści z 2005 roku: Kill? Romanzo di fantapolitica (Zabić? Powieść fikcji politycznej) Roberta Vacca i Chi ha ucciso Silvio Berlusconi? (Kto zabił Berlusconiego?) Giuseppe Carusa, w których istotnym elementem fabuły jest zabójstwo tego polityka.

Proces wychodzenia Zjednoczonego Królestwa z Unii Europejskiej, począwszy od przygotowań do czerwcowego referendum z 2016 roku, był szeroko dyskutowany w międzynarodowych mediach i bez wątpienia odbił się głośnym echem w kulturze Starego Kontynentu. Ze względu na aktualność brexitu, na napięcie, jakie wciąż wywołuje, oraz na fakt, że warunkuje życie licznych imigrantów, nietrudno postawić hipotezę, że w przyszłości stanie się jako motyw kulturowy jeszcze popularniejszy. Jego obecność w literaturze jest coraz bardziej widoczna, a przypuszczam, że w bliskiej przyszłości upowszechni się również w kinematografii, tak jak to miało miejsce we Włoszech w przypadku berlusconizmu.

W dyskursie krytyczno-literackim brexit został, jak dotąd, najobszerniej zanalizowany przez badaczy brytyjskich ${ }^{3}$. W monografii pod redakcją Roberta Eaglestone'a zatytułowanej Brexit and Literature: Critical and Cultural Responses (Brexit a literatura: krytyczne i kulturowe reakcje) (2018) zebrano artykuły cenionych naukowców pracujących w prestiżowych uniwersytetach w Zjednoczonym Królestwie. Z eseju wprowadzającego autorstwa Eaglestone’a Brexit and Literature (Brexit a literatura) czytelnik dowiaduje się, że w tomie uwzględniono kluczowe dzieła anglojęzyczne nawiązujące do brexitu, jak na przykład: Autumn (Jesień) (2016) Ali Smith, The Cut (Cięcie) (2017) Anthony'ego Cartwrighta i Exit West (Drzwi na Zachód) (2017) Mohsina Hamida4.

Do chwili obecnej we Włoszech zostały opublikowane trzy ważne powieści, które tematyzują interesujący mnie tutaj fenomen: Città irreale (Nierealne miasto) Cristiny Marconi, Brexit Blues (Brexitowy blues) Marca Varvella oraz La

3 Inne publikacje naukowe kompleksowo analizujące brexit nie zostały przeze mnie odnalezione. Niniejszy szkic jest pierwszą polskojęzyczną próbą opracowania tej problematyki we włoskiej literaturze współczesnej.

4 W 2018 roku we Francji została wydana powieść Clémentine Beauvais inspirowana zjawiskiem brexitu pod tytułem Brexit romance (Brexitowy romans), której akcja rozgrywa się głównie w Londynie ogarniętym społecznym napięciem towarzyszącym niedawno ogłoszonemu wynikowi referendum. Autorka uwypukla problemy, jakim Brytyjczycy i Francuzi będą musieli stawić czoła w związku z nadchodzącą zmianą prawa. Tytuł Brexit romance odwołuje się do działalności jednej z bohaterek - Justine Dodgson, zajmującej się organizacją białych małżeństw zawieranych, aby umożliwić Brytyjczykom otrzymanie francuskiego paszportu uprawniającego do swobodnego przemieszczania się po Wspólnocie. 
mia Brexit: diario di un comico nel posto giusto al momento sbagliato (Mój brexit: pamiętnik komika we właściwym miejscu o niewłaściwej porze) Francesca De Carla - wszystkie w 2019 roku. Ich autorzy, zawodowo związani z Wielką Brytanią, od dawna stanowiącą cel emigracji zarobkowej mieszkańców Półwyspu Apenińskiego5, bez wątpienia znakomicie poznali jej realia. Varvello jest londyńskim korespondentem telewizji Rai, Marconi dziennikarką, a De Carlo pracowal jako komik w Stand-up Comedy. Podejmowanie problematyki brexitu we włoskojęzycznej literaturze wydaje się typowe dla osób, które wcześniej nie zajmowały się pisarstwem i które obecnie przebywają poza granicami ojczyzny, a wymienione powyżej dzieła odzwierciedlają ich życiowe doświadczenia. Zastanawia mnie zatem, jakie aspekty brexitu są najbardziej widoczne u Marconi, Varvella i De Carla oraz czy i do jakiego stopnia stworzyli oni wspólny paradygmat obrazowania zjawiska.

Zacznę od powieści Marconi. Nie bez znaczenia jest w niej moment narracji, w którym temat brexitu pojawia się w bezpośredni sposób, a ma to miejsce w trzeciej, finalnej części utworu, stanowiącej podsumowanie losów bohaterki Aliny - alter ego samej autorki, a zwłaszcza jej ośmioletniego pobytu w Wielkiej Brytanii. Wizja nadchodzącej transformacji politycznej i związana z nią

5 Wielka Brytania od lat stanowi jeden z najpopularniejszych krajów, do których udają się Włosi. W latach 2012-2016 wyjechało tam aż 17\% z grona osób, które zdecydowały się na emigrację (Berti, Alberio 2020: 17). Od 2009 roku, czyli od momentu, kiedy we Włoszech rozpoczął się groźny kryzys ekonomiczny, emigracja stała się zjawiskiem coraz częstszym, a obecnie, jak słusznie twierdzą Fabio Berti i Marco Alberio (Berti, Alberio 2020: 7), ma masowy charakter. Elena Caneva (2016), cytowana w artykule Bertiego i Alberia, z którego korzystam, wyróżniła trzy typologie współczesnych włoskich emigrantów: „i delusi/insoddisfatti, gli esploratori, i mobili per indole” - „rozczarowani/ niezadowoleni”, „odkrywcy”, „mobilni z natury” (Berti, Alberio 2020: 20). Do pierwszej grupy zalicza tych, którzy narzekają na swoją sytuację ekonomiczną i brak perspektyw na lepsze życie w Italii. W drugiej grupie wymienia jednostki dokonujące zmiany przestrzeni życiowej, motywowane możliwością zdobycia nowych doświadczeń, dokonania nowych odkryć. Tak zwani „mobilni z natury” są definiowani jako „quei giovani nati e cresciuti in un contesto globale e che hanno fatto proprio e interiorizzato un habitus transnazionale: per loro trasferirsi da una città all'altra, muoversi, viaggiare, conoscere il diverso sono eventi ordinari e non eccezionali e quindi spostarsi in un altro paese è una possibilità tra tante, una strada da poter intraprendere” („młodzi, którzy urodzili się i dorastali w kontekście globalnym oraz przywiązali się do habitusu transnarodowego: dla nich przeprowadzka z jednego miasta do innego, przemieszczenie się, podróżowanie, poznawanie nieznanego są zwyczajnymi wydarzeniami, więc emigracja do innego kraju jest jedną z wielu możliwości, jedną z dróg, którą mogliby kroczyć”) (Berti, Alberio 2020: 20). Tłumaczenia tekstów obcych, o ile nie zaznaczono inaczej, pochodzą od Autora artykułu. 
atmosfera napięcia jawi się jako element strategii narracyjnej zmierzającej do podkreślenia zmian zachodzących w świecie wewnętrznym młodej dziewczyny.

Akcja ostatniego rozdziału powieści rozgrywa się w Rzymie, do którego Alina wraca, aby zdystansować się od wrażenia bycia „inną”, uczucia życiowej porażki i braku przynależności do brytyjskiej ziemi, które charakteryzowało ją zwłaszcza w początkowej fazie pobytu na obczyźnie, a które zupełnie niespodziewanie obudziło się ponownie w jej świadomości. Ta odważna i zdolna Włoszka, podobnie jak wielu innych przedstawicieli „pokolenia młodych”, dotkniętych skutkami kryzysu ekonomicznego z początku Xxi wieku, opuściła Italię, aby udać się do Londynu w poszukiwaniu nowych perspektyw. Jej życie w kosmopolitycznej stolicy było jednak naznaczone licznymi rozczarowaniami na płaszczyźnie zarówno zawodowej, jak i osobistej. Co ważne, z upływem czasu bohaterka zdołała osiągnąć pewną równowagę. W momencie, gdy czytelnik jest przekonany o jej stabilności emocjonalnej, zaczyna ona przeżywać kolejny kryzys tożsamości, wywołany, paradoksalnie, rozmową z angielskimi przyjaciółmi, którzy - motywowani niechęcią wobec imigrantów - podkreślili negatywne aspekty ich obecności w swoim kraju oraz wyrazili zamiar poparcia brexitu w zbliżającym się referendum. Według nich imigranci są zbyt liczni, wypierają Brytyjczyków na wielu płaszczyznach, utrudniając im życie.

Zastanawia mnie, czy to słuszne, że kraj zmienił się aż tak bardzo, przyjmując ludzi z całego świata, nawet jeśli są najbystrzejsi i najzdolniejsi. [...] To, co widzieliśmy w ostatnich latach, jest prawdziwym cyrkiem, zbyt wiele osób zostało. Mama opowiadała mi, że nie ma już angielskich koleżanek i że jej pacjenci są w większości obcokrajowcami. Trudno jest znaleźć miejsce w szkole, służby medyczne ledwo funkcjonują. W sumie, według mnie, należy to zahamować, ta sytuacja jest niewygodna dla wszystkich (Marconi 2019: 258) ${ }^{6}$.

Te niespodziewane słowa ludzi, których bohaterka znała od lat i uważała za przychylnych, utwierdziły ją w przekonaniu, że Londyn nigdy nie stanie się jej

6 „Però una domanda che mi faccio è se sia giusto che un paese venga completamente trasfigurato per far posto alle persone di tutto il mondo, tanto più se sono le più brillanti e dotate. [...] È un circo bellissimo, quello che si è visto negli ultimi anni, ma troppa gente è rimasta indietro. Mia madre mi racconta che non ha più colleghe inglesi e che anche i pazienti sono per la maggior parte stranieri. Trovare un posto a scuola è una fatica, i servizi sono al collasso. Insomma, secondo me ci vuole un freno, questa situazione è ingiusta per tutti." 
prawdziwym domem i zawsze będzie tam postrzegana przez pryzmat pochodzenia. Z tego powodu poczuła się tak wyobcowana jak nigdy wcześniej, pozbawiona ojczyzny i tożsamości narodowej. Jako migrantka od lat była zawieszona między dwoma przestrzeniami życiowymi, miała jednak nadzieję, że proces integracji, któremu poddała się z wyboru, pozwoli jej utożsamiać się z krajem, do którego przybyła i który pokochała. Widmo brexitu oraz stosunek Anglików do obcokrajowców sprawiły, że zrozumiała, iż owa nadzieja była złudna. Co więcej, kobieta nie wyraża odczuwanego żalu, woli stłumić go w sobie tak, aby inni uważali, że akceptuje własne położenie. Nazywa się „obcą” i wyraża współczucie wobec autochtonów: „często zastanawiałam się, jak to jest widzieć, że własny kraj zmienił się tak bardzo, to nie jest coś, o czym my, obcokrajowcy, nie myślimy" (Marconi 2019: 259)7.

Narracja Marconi świetnie oddaje charakter wpływu, jaki miała na angielskie społeczeństwo propagandowa akcja konkretnych środowisk politycznych w kampanii przed referendum w sprawie brexitu. Jak podkreślają Stefania Marino i Giuseppe D’Onofrio, hasła antyimigracyjne głoszone przez partie centroprawicowe stały się wówczas szczególnie toksyczne (Marino, D’Onofrio 2017: 61). Imigrantów obarczono winą za coraz poważniejsze problemy społeczno-ekonomiczne kraju, ukazano ich jako „drapieżników” otrzymujących zbyt wiele korzyści finansowych od brytyjskiego państwa.

Bezpośrednie nawiązanie do tematu imigracji odgrywa ważną rolę w obrazowaniu brexitu w dziele Marconi. Pozwala zrozumieć trudne położenie egzystencjalne bohaterki, a w szerszej perspektywie - również siłę odziaływania informacji o brexicie na tożsamość narodową włoskich imigrantów w Londynie. Ów temat ma podobny status w utworze Varvella, w którym warunki życia obcokrajowców oraz ich relacje z Brytyjczykami są szeroko analizowane i stanowią rdzeń wizji brexitu.

Powieść Brexit Blues charakteryzuje specyficzna, dwupoziomowa struktura narracyjna, wyraźnie oznaczona za pomocą kursywy również w podziale na rozdziały. Pierwszy poziom stanowi narracja pierwszoosobowa, którą autor stosuje, aby opowiedzieć o trudach egzystencji imigranta w Londynie. Na drugim poziomie - mimo przyjęcia trzecioosobowej narracji - elementy autobiograficzne również zdecydowanie dominują. Rolę głównego spoiwa, łączącego dwa wyróżnione poziomy, pełni problematyka brexitu, naszkicowana przez Varvella w szerokiej perspektywie chronologicznej obejmującej rzeczywistość przed i po referendum. Autor posługuje się konkretną techniką narracyjną: z jednej strony

7 „Io me lo sono chiesta spesso, cosa vuol dire vedere il proprio paese trasformato così tanto, non è una cosa a cui noi stranieri non pensiamo." 
często prezentuje argumenty zwolenników opuszczenia Unii Europejskiej przez Wielką Brytanię, z drugiej zaś opisuje sytuacje udowadniające, że ich motywacja nie jest słuszna. W tym miejscu odwołam się do cytatu:

To właśnie Zjednoczone Królestwo nauczyło świat podstaw funkcjonowania Welfare State. Anglicy są z tego dumni, a zarazem nie bez słuszności są o to zazdrośni. Nie można byłoby więc uniknąć sytuacji, w której brexitowa propaganda nie zarzuciłaby obcokrajowcom, że pobierają zbyt wiele zasiłków. Ów zarzut szybko stał się kluczowym punktem: „Jesteśmy małą wyspą, dłużej już nie damy rady”, mówił [...] Nigel Farage podczas kampanii referendalnej, [...] komentując, jak bardzo imigranci obciążyli system świadczeń publicznych (Varvello 2019: 36) ${ }^{8}$.

Przedstawione w powieści osoby popierające brexit utrzymują, że - ze względu na dobrze rozwinięty system opieki społecznej - imigranci czerpią zbyt duże korzyści finansowe, przyczyniając się do obniżenia jakości życia rdzennych mieszkańców. Redukcja ich napływu z krajów Unii Europejskiej pozwoliłaby politykom przeznaczyć więcej środków na te obszary funkcjonowania społeczeństwa, które przeżywają kryzys, jak np. szkolnictwo i służba zdrowia, a są niezmiernie ważne $\mathrm{z}$ punktu widzenia wszystkich obywateli państwa. $\mathrm{W}$ tym kontekście narrator relacjonuje historię angielskiej dziewczyny - samotnej matki niemowlęcia, która w obliczu braku możliwości utrzymania siebie i dziecka opuszcza Bradford i udaje się do Berlina, gdzie jest w stanie skonstruować nową przestrzeń życiową, a jej trudna sytuacja poprawia się znacząco. Bohaterka krytykuje ojczyznę, gdyż nie mogłaby tam liczyć na pomoc finansową i lepsze perspektywy, Niemcy postrzega zaś jako „ziemię obiecaną”:

Tutaj nie obcięli zasiłków tak, jak w Bradford, w Yorkshire, w Anglii i w tym całym przeklętym Zjednoczonym Królestwie. Samotna matka to samotna matka. Pomożemy jej. Jest zasiłek na dziecko i na mnie, ponieważ zostaję w domu i nie pracuję. Dodatek, ponieważ nie mam dochodu, aby pomóc opłacić czynsz i rachunki. I oczywiście żłobek.

8 „Proprio il Regno Unito ha insegnato al mondo l'abc del Welfare State. Gli inglesi ne sono orgogliosi e anche legittimamente gelosi. Era inevitabile dunque che la propaganda di Brexit cavalcasse anche la denuncia dei troppi benefits regalati agli stranieri. È stato subito un punto cruciale: «We are a small island, we can't cope anymore» [...] rispondeva Nigel Farage durante la campagna per il referendum, [...] riferendosi al peso degli immigrati sui servizi pubblici." 
Alfie mógłby pójść tam od razu za darmo. [...]. Mam pieniądze na czynsz i godne życie (Varvello 2019: 71-72).

Ta historia rzuca nowe światło na obraz imigracji rozpowszechniany przez zwolenników brexitu. Varvello podkreśla, że nie tylko imigranci w Wielkiej Brytanii korzystają z systemu opieki społecznej, lecz czynią tak również brytyjscy obywatele na stałe przebywający na terenie Unii, gdyż taką możliwość gwarantują im wspólnotowe regulacje prawne.

Autor niewątpliwie stara się ukazać obcokrajowców w korzystnym świetle. Opowiada o ich związkach z Brytyjczykami, o szczęśliwych rodzinach, które z nimi tworzą, o bogactwie kulturowym, które się dzięki nim pojawia. Uwypukla wkład, jaki wnoszą w rozwój kraju, wymieniając wiele obszarów ekonomicznych funkcjonujących sprawnie tylko dzięki ich pracy i poświęceniu.

Varvello popiera ideę Europy bez granic, swobodę przemieszczania się tak, aby każdy - bez względu na narodowość - mógł realizować swoje plany i potrzeby. W tym kontekście brexit jawi się jako fenomen blokujący jednostkę, ograniczający jej indywidualność, wymuszający izolację, a więc jako zdecydowanie niesprawiedliwy, stanowiący duże zagrożenie, prawdziwą barierę $\mathrm{w}$ realizacji fundamentalnych praw każdego człowieka. Rozczarowuje, gdyż kwestionuje podwaliny powszechnie akceptowanego ładu i aktualność tak ważnych haseł, jak: europejskość oraz wspólnotowość, pozbawia Europę wartości płynących ze zjednoczenia, ogranicza sens istnienia Wspólnoty jedynie do wymiaru politycznego i finansowego:

Widzimy, jak podnoszone są kotwice projektu europejskiego, który chyli się ku upadkowi. W gruncie rzeczy jest to najsmutniejszy blues. Kres projektu zjednoczonej Europy. Przez dziesięciolecia cynizmu widzieliśmy, jak podupadał i ulatniał się. Odebraliśmy go najmłodszym pokoleniom. Ustąpił miejsca wyczerpanemu i uległemu bluesowi. Rozczarowanie, utrata przekonania, że jest możliwa pozytywna zmiana $\mathrm{w}$ relacjach między ludźmi oraz $\mathrm{w}$ instytucjach, którym powierzamy nasze wspólne sprawy. [...] Nie dziwi, że po latach antyeuropejskiej retoryki w Wielkiej Brytanii wygrał brexit w referendum z 2016. Nie

9 „Qui non hanno tagliato i benefits come hanno fatto a Bradford, nello Yorkshire, in Inghilterra e in tutto il fottuto Regno Unito. Una madre single è una madre single. Diamole una mano. Cè il sussidio per il bambino e uno perché sto a casa senza lavorare. Un arrotondamento perché non ho reddito, compreso un aiuto per pagare l'affitto e le bollette. E ovviamente l'asilo. Alfie potrebbe già andare al nido. [...] Ho soldi per l'affitto e per vivere decentemente." 
dziwi, że po latach propagandy skierowanej przeciw Brukseli, przeciw jej regulacjom i biurokracji, Europa stała się jedynie szkieletem monetarnym i finansowym (Varvello 2019: 163-164) ${ }^{10}$.

W mającej formę pamiętnika powieści La mia Brexit Francesca De Carla wizja brexitu, podobnie jak w dwóch wcześniej analizowanych dziełach, okazuje się ściśle powiązana z problematyką imigracji. Perspektywa chronologiczna obejmuje okres tuż po referendum z 2016 roku. Narrator, imigrant przebywający w Wielkiej Brytanii, opowiada o tym, jak zbliżające się wyjście z Unii Europejskiej wpływa na jego życie zawodowe. Wymienia liczne negatywne skutki decyzji Brytyjczyków, obawiając się najbardziej konieczności wyjazdu. Paradoksalnie dostrzega również pozytywny aspekt swojej sytuacji: jako komik otrzymuje propozycję przygotowania wystąpienia poświęconego brexitowi i odnosi korzyść finansową, zdobywając uznanie londyńskiej publiczności. Jednak gdy wyjeżdża pracować poza stolicę, do tych miejsc, gdzie większość mieszkańców poparła brexit, spotyka się z krytyczną reakcją widzów wywołaną jego obcym pochodzeniem, łatwo zauważalnym ze względu na wygląd oraz włoski akcent. Fakt, że jest Włochem - przedstawicielem kultury śródziemnomorskiej - stanowi główną przesłankę skłaniającą Brytyjczyków do wyrażenia dezaprobaty.

Powieść świetnie obrazuje to, jak brexit prowadzi do powstania i zaostrzenia się specyficznego konfliktu, do ostrego starcia kultury południowej z kulturą północną. W Wielkiej Brytanii kultura południowa kojarzona jest bowiem z kryzysem imigracyjnym oraz wynikającą z niego zapaścią sanitarną i ekonomiczną, budzącą obawy i niechęć. Włosi udający się na brytyjskie ziemie są tam postrzegani jako jednostki, które uciekają przed negatywnymi zjawiskami społecznymi w ojczyźnie, a jednocześnie przyczyniają się do intensyfikacji bardzo podobnych zjawisk, stając się imigrantami. De Carlo walczy z takim stereotypowym podejściem, twierdząc, że oprócz nadziei na lepsze perspektywy

10 „In molti vediamo cedere gli ormeggi del disegno europeo, che rischia di andare alla deriva. Il blues più triste in fondo è proprio questo. Il tramonto del progetto europeo di un'Europa più unita. In decenni di cinismo lo abbiamo visto erodersi ed evaporare. Lo abbiamo negato alle generazioni più giovani. Ha lasciato posto a un blues estenuato e rinuncitario. Delusione, perdita della convinzione che un progresso sia possibile nei rapporti tra le persone e nelle costruzioni istituzionali a cui affidiamo la nostra convivenza di esseri umani. [...] Non stupisce che dopo decenni di retorica antieuropea in Gran Bretagna abbia vinto Brexit nel referendum 2016. Non stupisce che dopo anni di propaganda contro Bruxelles, contro i suoi vincoli e la sua burocrazia, l'Europa sia ridotta a uno scheletro monetario e finanziario." 
zawodowe, Wielka Brytania przyciąga Włochów w szczególności ze względu na bogactwo wielowiekowej tradycji i unikatowe kulturowe piękno.

Z perspektywy imigranta przestrzeń kultury północnej, której wyższość zostaje w powieści wyraźnie uwypuklona, oferuje rozwój na wielu płaszczyznach, a w obliczu odrzucenia powoduje rozpacz i zmusza do poszukiwania nowych życiowych ścieżek oraz głębokich refleksji na temat własnego położenia. Sytuacja odrzucenia stanowi punkt zwrotny w życiu bohatera powieści, uświadamia mu, kim jest i jak powinien zachować się w przyszłości.

Jako imigrant w Wielkiej Brytanii De Carlo doświadczył niechęci ze strony Brytyjczyków, lecz dzięki temu zdał sobie sprawę z faktu, że jego egzystencja jest ciągłą migracją, do której skłonność otrzymał w spadku po przodkach, i którą postanowił potraktować jako dar, szansę na wzbogacenie osobowości oraz odkrycie nowych miejsc i kultur:

Gdyby w przeszłości nie dochodziło do migracji, ja sam nie istniałbym. Jestem emigrantem, synem emigrantów: mój ojciec jest Kalabryjczykiem, a matka jest Sardynką. Oboje przeprowadzili się do Rzymu, gdzie zakochali się i gdzie ja urodziłem się i dorastałem. Istoty ludzkie po tym, jak są migrantami, stają się osiedleńcami, osiedlają się. A co zrobię ja? Chcę mieć dom. Ale gdzie? [...] Pojadę tam, gdzie kieruje mnie serce czy głowa? A gdy zastanawiałem się, co zrobić [...], zdałem sobie sprawę, że nigdy nie byłem w Nowym Yorku (De Carlo 2019: 163) ${ }^{11}$.

Sytuacja odrzucenia, w której znalazł się De Carlo, oznaczająca brak możliwości zrobienia kariery i realizacji ambicji zawodowych, niewątpliwie wpłynęła również na strategię narracyjną analizowanej powieści. Jej istotnym aspektem jest bowiem krytyka brytyjskiego społeczeństwa, przede wszystkim w kontekście jego stosunku do imigrantów i ogólnie do zjawiska imigracji. Podczas wystąpień artystycznych autor nie wahał się wyrażać bezpośrednio swoich przemyśleń o mieszkańcach Wielkiej Brytanii, ironicznie zarzucając im ksenofobię oraz niesprawiedliwe podejście do cudzoziemców:

11 „Se in passato non ci fossero state migrazioni io stesso non esisterei. Io sono un emigrante, figlio di emigranti: mio padre è calabrese, mia madre è sarda, ed entrambi si sono trasferiti a Roma, dove si sono innamorati e dove io sono nato e cresciuto. Ma gli esseri umani, dopo essere migranti, diventano stanziali, si stanziano. E io cosa farò? Io voglio una casa. Ma dove? [...] Vado dove mi porta il cuore o la capoccia? E mentre ragionavo sul da farsi [...], mi resi conto di non essere mai stato a New York.” 
Przegłosowaliście brexit, ponieważ nie chcecie obcokrajowców takich, jak ja. A więc lubicie Włochy, ale nie Włochów. Rozumiem to, mam tak samo: lubię Londyn, nie lubię was. Gdziekolwiek się pojedzie, jest tak, że świat jest cudowny, lecz ludzie są okropni (De Carlo 2019: 98) ${ }^{12}$.

Brytyjczycy zostają ukazani w powieści jako naród bardzo zamknięty, charakteryzujący się ogólną niechęcią do nawiązywania nowych kontaktów, a wręcz strachem przed drugim człowiekiem. Odnosząc się do referendum, De Carlo wyśmiewa ich niestabilność i dużą nieprzewidywalność:

Poprzez referendum udowodniliście, że wszystko jest możliwe. Nic już nas nie zdziwi: teraz Trump mógłby zostać prezydentem Stanów Zjednoczonych, obcy w końcu mogliby ujawnić swoją obecność lub, kto wie, Anglia mogłaby wygrać mistrzostwa świata w piłce nożnej (De Carlo 2019: 124) ${ }^{13}$.

Wyraźnie zatem podkreśla, że dokonanie się brexitu pogłębi trwający od momentu ogłoszenia wyniku referendum kryzys pokolenia Europejczyków wychowanych w poczuciu jedności państw Unii i przywykłych do przywilejów, a zwłaszcza do swobodnego podróżowania pozwalającego na realizację marzeń. Co więcej, doprowadzi do nasilenia antagonizacji i tak już bardzo podzielonego społeczeństwa Zjednoczonego Królestwa.

Szkicując bardzo niekorzystny obraz rdzennych mieszkańców Wielkiej Brytanii, autor widzi możliwość jego modyfikacji w przyszłości i wyraża nadzieję, że Brytyjczycy zmienią swoje postępowanie wobec imigrantów. Wzywa ich wręcz do zatrzymania zła, jakim jest brexit:

Jeśli wyobrazimy sobie, że Europa jest wielkim przyjęciem, wy byliście didżejem, który wybierał płyty. Teraz jesteście dziwnym chłopcem, który stoi sam w rogu i chce wrócić do domu. [...] Pozostańcie otwarci, nie zmieniajcie się, nie bójcie się obcokrajowców, porzućcie swoje wygodne podejście tak, abyśmy mogli wymienić się pomysłami, kulturami,

12 „Avete votato la Brexit perché non volete stranieri come me. Quindi vi piace l'Italia, ma non vi piacciono gli italiani. Lo capisco, per me è la stessa cosa: mi piace Londra, non mi piacete voi. Ovunque andate è così: il mondo è meraviglioso, la gente fa schifo."

13 "Con il referendum avete provato che tutto è possibile. Non ci stupiremo più di niente: adesso Trump potrebbe diventare presidente degli USA, gli alieni potrebbero finalmente farsi vivi oppure, chissà, l'Inghilterra potrebbe vincere la Coppa del mondo di calcio." 
chorobami wenerycznymi i tym wszystkim, co sprawia, że czujemy, że żyjemy (De Carlo 2019: 150) $)^{14}$.

Jak wynika z powyższych analiz, włoska literatura współczesna stworzyła dość homogeniczny paradygmat obrazowania brexitu. We wszystkich trzech przywołanych powieściach ukazano brexit jako zjawisko bardzo negatywne, blokujące bohaterów, powodujące silne napięcie, lęk, rozdarcie, rozterki tożsamościowe i zmuszające do podjęcia trudnych życiowych decyzji. Zostało ono osadzone w szerokim kontekście problematyki imigracji w Wielkiej Brytanii, pozwalając autorom scharakteryzować i skrytykować stosunek części Brytyjczyków do obcokrajowców. Autobiograficzne narracje Marconi, Varvella i De Carla jawią się jako silnie zaangażowane. Demaskują niesprawiedliwość brexitu, jego destrukcyjne oddziaływanie na jednostkę oraz na funkcjonowanie całej europejskiej wspólnoty, nadają mu charakteru katalizatora populizmu i społecznych podziałów. Sugerują również, że nie wszystko jest stracone i można by jeszcze spróbować zmienić rzeczywistość. Mimo że w omawianych powieściach na horyzoncie pojawiło się widmo ogromnego kryzysu, nie doszło jeszcze do opuszczenia Unii Europejskiej przez Wielką Brytanię. Narracja Marconi ogranicza się do okresu przed referendum, Varvello opowiada o realiach zarówno przedreferendalnych, jak i poreferendalnych, wizja De Carla obejmuje zaś przede wszystkim rok 2016, w którym ogłoszono wynik głosowania. Czytelnik jest jednak świadomy, że owa sugestia, wyrażająca nadzieję na przyszłość, nie zostanie zrealizowana. Brexit stał się faktem.

\section{| Bibliografia}

Berti Fabio, Alberio Marco (2020), Italiani che lasciano l'Italia. Le nuove emigrazioni tra continuità e cambiamenti, w: Italiani che lasciano l'Italia. Le nuove emigrazioni tra continuità e cambiamenti, red. Berti Fabio, Alberio Marco, Mimesis Edizioni, Milano-Udine, s. 7-32.

Beauvais Clémentine (2018), Brexit romance, Sarbacane Éditions, Paris.

14 „Se immaginate l'Europa come un grande party, voi eravate il dj che mette i dischi. Adesso siete il ragazzo strano, quello che sta da solo in un angolo e vuole tornare a casa. [...] Restate aperti, non cambiate, non abbiate paura degli stranieri, uscite dalla vostra comfort zone, così possiamo scambiarci idee, culture, malattie veneree e tutto quello che ci fa sentire vivi." 
Berezowski Łukasz (2009), Zabić Berlusconiego? Współczesna polityka włoska widziana oczami twórców kultury, w: Współczesne Włochy. Państwo i Społeczeństwo, red. Tomasz Słomka, ASPRA-JR, Warszawa, s. 117-134.

Berezowski Łukasz (2013), Władza i polityka $w$ literaturze political fiction: prawda czy fikcja?, Wydawnictwo Uniwersytetu Warszawskiego, Warszawa.

Caneva Elena (2016), Giovani italiani che emigrano: percorsi di vita inediti all'epoca della crisi ecoonomica globale, „Mondi Migranti”, nr 3, s. 79-93.

Caruso Giuseppe (2005), Chi ha ucciso Silvio Berlusconi?, Ponte alle grazie, Firenze.

Cartwright Anthony (2017), The Cut, Peirene Press, London.

Chwin Stefan (2006), Żona prezydenta, Wydawnictwo Tytuł, Gdańsk.

De Carlo Francesco (2019), La mia Brexit. Diario di un camico nel posto giusto al momento sbagliato, Bompiani, Milano.

Eaglestone Robert, red. (2018), Brexit and Literature: Critical and Cultural Responses, Routledge, Abingdon.

Eaglestone Robert (2018), Introduction: Brexit and Literature, w: Brexit and Literature: Critical and Cultural Responses, red. Robert Eaglestone, Routledge, Abingdon.

Golemo Karolina (2013), Berlusconizm, czyli o włoskich kłopotach z kultura polityczna w epoce Silvia Berlusconiego, w: Teoretyczne i praktyczne problemy kultury politycznej: studia i szkice, red. Monika Banaś, Księgarnia Akademicka, Kraków, s. 119-140.

Hamid Mohsin (2017), Exit West, Hamish Hamilton, London.

Janaszek-Ivaničkowá Halina (2012), Political fiction w literaturze polskiej pierwszej dekady XXI wieku, „Litteraria Humanitas”, nr XVI, s. 105-113.

Marconi Cristina (2019), Città irreale, Adriano Salani Editore, Milano.

Marino Stefania, D’Onofrio Giuseppe (2017), La Brexit e l'immigrazione italiana «di nuova generazione» nel Regno Unito, „La Rivista delle Politiche Sociali”, nr 4, s. 53-76.

Smith Ali (2016), Autumn, Hamish Hamilton, London.

Vacca Roberto (2005), Kill? Romanzo di fantapolitica, Marsilio, Padova.

Varvello Marco (2019), Brexit Blues, Mondadori, Milano.

Wojciechowski Piotr (2007), Doczekaj nowiu, Świat Książki, Warszawa. 


\section{| Abstrakt}

KAROL KARP

Brexit we włoskiej literaturze współczesnej: Città irreale (Nierealne miasto) Cristiny Marconi, Brexit Blues (Brexitowy blues) Marca Varvella i La mia Brexit (Mój brexit) Francesca De Carla

Przedmiotem artykułu jest fenomen brexitu we włoskiej literaturze współczesnej, rozpatrywany na podstawie opublikowanych dotychczas tekstów, w których odgrywa on istotną rolę. Analizie zostają poddane trzy powieści: Città irreale (Nierealne miasto) Cristiny Marconi, Brexit Blues (Brexitowy blues) Marca Varvella oraz $\mathrm{La}$ mia Brexit (Mój brexit) Francesca De Carla, z których wyłania się jego negatywny obraz, osadzony w kontekście problematyki imigracji, stanowiącej szczególny obszar zainteresowania wymienionych autorów.

Słowa kluczowe: brexit; literatura włoska; imigracja; kryzys

\section{| Abstract}

KaROL KARP

Brexit in Italian Contemporary Literature: Città irreale (Unreal city) by Cristina Marconi, Brexit Blues (Brexit Blues) by Marco Varvello and La mia Brexit (My Brexit) by Francesco De Carlo

The subject of the article is the phenomenon of Brexit in contemporary Italian literature investigated on the basis of the texts published so far, in which it plays an important role. Three novels are analyzed: Città irreale by Cristina Marconi, Brexit Blues by Marco Varvello and La mia Brexit by Francesco De Carlo, from which emerges negative image of Brexit, set in the context of immigration, which is a special area of interest for the above-mentioned authors.

Keywords: Brexit; Italian literature; immigration; crisis

\section{| Biogram}

Karol Karp - prof. Uмк. Obszar jego badań obejmuje współczesną literaturę włoską ze szczególnym uwzględnieniem jej nurtu migracyjnego. Uczestniczył w wielu 
międzynarodowych konferencjach, odbył staże naukowe we włoskich ośrodkach akademickich. Publikuje w kraju i za granicą, w języku polskim i włoskim. W jego dorobku znajdują się dwie monografie, dwie monografie pod redakcją, liczne artykuły oraz kilka recenzji. Jest członkiem dwóch stowarzyszeń naukowych: Associazione Internazionale dei Professori d'Italiano i Stowarzyszenia Italianistów Polskich. E-mail: karp@umk.pl

ORCID: 0000-0002-9449-8297 